\title{
Tooth loss and risk of colorectal cancer: a dose-response meta-analysis of prospective cohort studies
}

This article was published in the following Dove Press journal: OncoTargets and Therapy

Peng Ma

Shaojun Dai

Can Jin

Yonggang Yao

Chuanxin Zou

Department of Gastroenterology, The Second Clinical Medical College, Yangtze University, Jingzhou, Hubei Province, People's Republic of China
Correspondence: Chuanxin Zou Department of Gastroenterology, The Second Clinical Medical College, Yangtze University, Jing Road 60, Jingzhou 434000, Hubei Province, People's Republic of China Email chuanxinzou@sina.com
Background: Previous studies have indicated that tooth loss is associated with colorectal cancer risk but have presented controversial results.

Methods: We conducted a dose-response meta-analysis in order to investigate the correlation between tooth loss and colorectal cancer risk. Up to August 2017, six eligible studies were included in this meta-analysis.

Results: Our results showed statistically significant association between tooth loss and colorectal cancer $(\mathrm{OR}=1.08,95 \% \mathrm{CI}: 1.03-1.15, P<0.001)$. In addition, we obtained the best fit at an inflection point of every two tooth loss in piecewise regression analysis, and the summary relative risk (RR) of colorectal cancer for an increase of every two tooth loss was 1.06 (95\% CI: 1.02-1.11, $P<0.001)$. Furthermore, tooth loss was significantly associated with colorectal cancer risk in Caucasia (RR: 1.18; 95\% CI: 1.09-1.28; $P<0.001$ ) and Asia (RR: 1.06; 95\% CI: $1.02-1.10 ; P<0.001$ ). Moreover, tooth loss was significantly associated with a higher risk of colon cancer (RR: 1.09 ; 95\% CI: 1.02-1.17; $P<0.001$ ) and rectal cancer (RR: 1.08; 95\% CI: $1.01-1.17 ; P<0.001$ ).

Conclusion: Subgroup meta-analyses showed consistency with the primary findings. Considering these promising results, increasing tooth loss may be harmful to our health, and maintenance of our oral health is essential.

Keywords: colorectal cancer, tooth loss, dose-response relationship, meta-analysis

\section{Introduction}

Colorectal cancer is the third most common cancer worldwide, and it costs patients, caregivers, and society. ${ }^{1}$ According to the statistics of the American Cancer Association, colorectal cancer mortality has gradually increased, while the overall cure rate for colorectal cancer has not improved significantly over the past decade. ${ }^{2,3}$ Every year, as many as 930,000 newly patients are diagnosed with colorectal cancer across the world. ${ }^{2}$ Due to differences in countries' geographical environment and living habits, the incidence of colorectal cancer is different in various regions, being the most severe in developing countries such as Africa, Asia, and South America and higher in developed countries than in developing countries. Residents of North America and Europe are the most vulnerable to colorectal cancer, but China has a large population base, making it the country with the highest number of cancer deaths throughout the world. ${ }^{2}$

There are a few identified risk factors for colorectal cancer, including polyp formation, schistosomiasis, and chronic nonspecific ulcerative colitis. Understanding the impact of environmental factors on colorectal cancer will help to prevent colorectal cancer. Previous studies have showed that oral health is emerging as an independent risk factor for health. 
Oral health is an important part of human health. The World Health Organization (WHO) identifies dental health as one of the top 10 criteria for human health. Poor oral health may increase systemic inflammation, resulting in a local overly aggressive immune response and thus could have important implications for cancer development. Periodontal disease and tooth loss are two common oral health problems. ${ }^{4}$ Colitis, an acute inflammatory state in the colon, is the basis for developing colorectal cancer in majority of the patients, and tooth loss is an independent risk factor for colitis. In addition, tooth loss has been considered to affect quality of life ${ }^{5}$ and has been known to considerably influence food choice, diet, nutrition intake, and aesthetics. ${ }^{6}$

Previous studies have reported that tooth loss significantly increases the risk of colorectal cancer. However, the result remains controversial. ${ }^{7-12}$ Therefore, we have conducted this comprehensive meta-analysis to clarify the correlation between tooth loss and colorectal cancer risk.

\section{Methods}

\section{Search strategy}

We conducted a systematic literature search of Medline and Embase up to August 2017 to examine the association between tooth loss and colorectal cancer risk. The search terms were "Colorectal Neoplasms" [MeSH] OR "Colorectal Tumor" [MeSH] OR “Colorectal Cancer” [MeSH] OR "Colorectal Carcinoma" [MeSH] OR "Cancer of Breast" [MeSH] AND "Dentition" [MeSH] OR "Tooth Loss" [MeSH] OR "Edentulous" [MeSH] OR "Loss of Tooth" [MeSH].

\section{Data extraction}

Investigators independently collected information if the following criteria were met: (1) the outcome was colorectal cancer; (2) risk estimates on the relationship between tooth loss and colorectal cancer risk were provided. According to the Newcastle-Ottawa scale, quality assessment was performed for nonrandomized studies. ${ }^{13}$

\section{Statistical analysis}

Stata software 14.0 (StataCorp LP, College Station, TX, USA) was used in all analyses. Due to different definitions for the cutoff points for categories in the included studies, we calculated the RR estimates by the method recommended by Greenland and Longnecker, as well as Orsini et al. ${ }^{14,15}$

\section{Results}

\section{Literature search results}

A total of 2,501 studies from Medline, 3,023 studies from Embase were screened. After removing duplicates,
2,818 studies were identified. Reviewing their titles and abstracts, 2,760 citations were excluded. The remaining 58 citations were assessed in more detail for eligibility by reading the full text. Among them, 18 studies were excluded due to no relevant outcome measure; 23 studies were excluded because they were not human studies; nine studies were excluded as they were reviews; and three studies were excluded due to lack of detailed information. After review of the references of the studies, one article was identified for rejection. Finally, six studies were used for the final data synthesis. The flow chart of the literature search is presented in Figure 1.

\section{Study characteristics}

The characteristics of the included studies are shown in Tables 1 and 2. Among the selected studies, six studies were eligible, including four cohort studies and two case-control studies; three studies were on Caucasia and three were on Asia; a total of 160,182 participants with 8,309 incident cases were included in this meta-analysis.

\section{Overall meta-analysis}

Six eligible studies identified the relationship between tooth loss and colorectal cancer risk. Compared with the reference category, tooth loss is significantly associated with colorectal cancer risk (relative risk [RR]: 1.08; 95\% CI: 1.02-1.15; $P=0.011$ ) (Figure 2). We found no evidence of between-study heterogeneity $\left(I^{2}=20.5 \%, P=0.115\right)$ and we observed no evidence of publication bias (Egger asymmetry test, $P=0.239$ ) (Table S1).

\section{Dose-response meta-analyses between tooth loss and colorectal cancer}

A dose-response analysis showed that every two incremental increase in tooth loss was associated with a $6 \%$ increment in the risk of colorectal cancer; the summary RR of colorectal cancer for an increase of every 10 in tooth loss was 1.06 (95\% CI: 1.02-1.11, $P<0.001$ ) (Figure 3).

\section{Subgroup analyses}

Subgroup analysis based on study location found a similar risk increment of colorectal cancer in Asia (OR $=1.06$; 95\% CI: $1.02-1.10 ; P<0.001)$ and Caucasian $(\mathrm{OR}=1.18$, 95\% CI: 1.09-1.28; $P<0.001$ ) (Table 3 ). In addition, tooth loss is significantly associated with a higher risk of colon cancer (RR: 1.09; 95\% CI: 1.02-1.17; $P<0.001$ ) and rectal cancer (RR: $1.08 ; 95 \% \mathrm{CI}: 1.01-1.17 ; P<0.001$ ) (Table 3 ). The relationship between tooth loss and colorectal cancer risk was similar in subgroup analyses, which were 


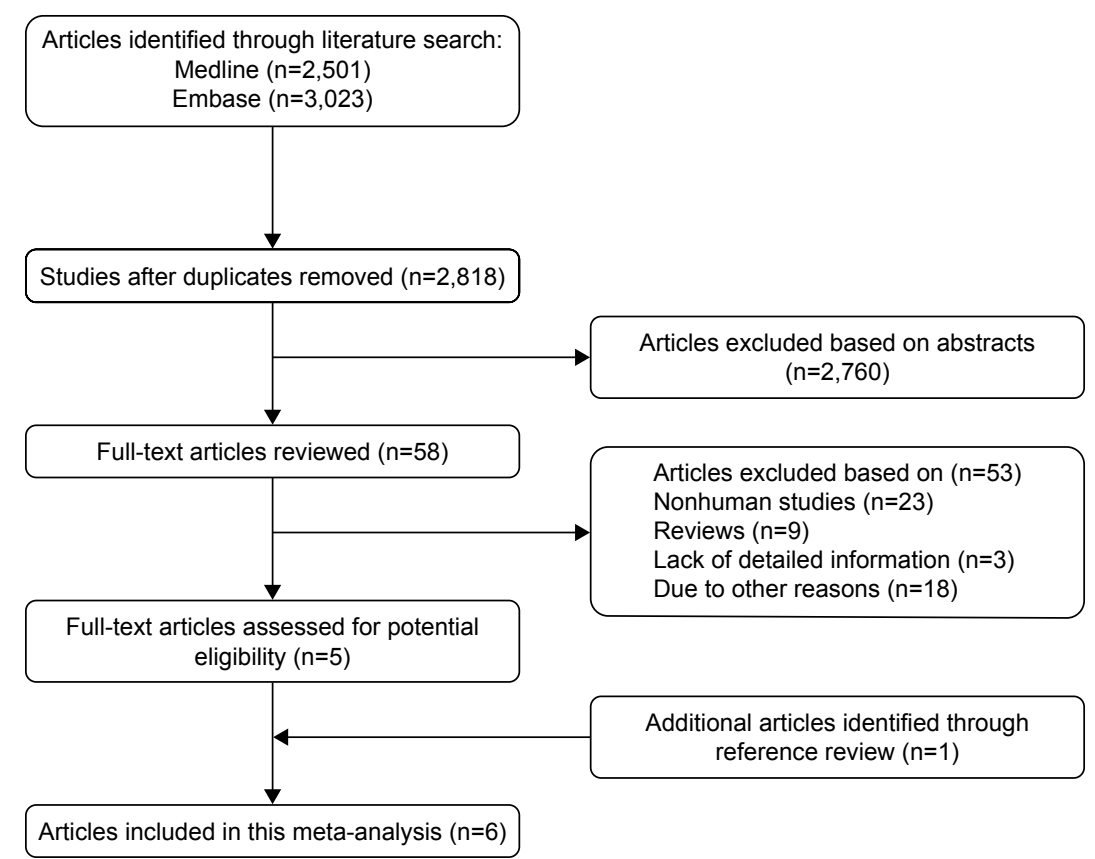

Figure I Flow diagram of the study selection process.

defined by study design, number of cases or participants, and study quality.

\section{Publication bias}

Publication bias of tooth loss and colorectal cancer was evaluated with both Begg's and Egger's tests (Table S1). A funnel plot for the assessment of publication bias is illustrated in Figure S1.

\section{Discussion}

Colorectal cancer affects millions of people in developed and developing countries and is now a public health crisis. Despite the decline in the mortality rate in developed countries, colorectal cancer has caused serious social and economic distress on a global scale over the past few decades. In low- and middle-income countries, the incidence of colorectal cancer has risen sharply. ${ }^{2}$ A link between tooth loss and all-cause mortality has been proposed, and there is evidence of a possible association between tooth loss and atherosclerotic vascular disease. However, studies of tooth loss in colorectal cancer have increased slowly, and the results are inconsistent.

Hiraki et a ${ }^{10}$ found that increasing teeth loss was associated with risk of head and neck cancer, esophageal cancer, and lung cancer but not colon cancer and ovarian cancer. Michaud et $\mathrm{al}^{9}$ showed that tooth loss was associated with an increased risk of total cancer, lung cancer, kidney cancer, and pancreatic cancer but not colorectal cancer. MomenHeravi et $\mathrm{al}^{8}$ showed that increasing loss in number of teeth was associated with risk of colorectal cancer. Ren et $\mathrm{al}^{7}$ found no evidence supporting an association between teeth loss and colorectal cancer risk in three cohort studies. Ansai et $\mathrm{al}^{11}$ showed that tooth loss was associated with increased colorectal cancer in the Japanese population. Hujoel et al ${ }^{12}$ showed that increasing teeth loss was not associated with risk of colorectal cancer. Collectively, these data suggest that teeth loss may play an important role in colorectal cancer risk. However, the result remains controversial. Thus, we

Table I Characteristics of participants in the included studies on tooth loss in relation to risk of colorectal cancer

\begin{tabular}{|c|c|c|c|c|c|c|c|}
\hline Author (year) & $\begin{array}{l}\text { Study } \\
\text { design }\end{array}$ & Country & $\begin{array}{l}\text { Sex of } \\
\text { population }\end{array}$ & $\begin{array}{l}\text { Age at } \\
\text { baseline (years) }\end{array}$ & $\begin{array}{l}\text { Number of } \\
\text { participants }\end{array}$ & End points (cases) & $\begin{array}{l}\text { Quality } \\
\text { score }\end{array}$ \\
\hline Hiraki et al ${ }^{10}$ (2008) & Case-control & Japan & Mix & 58 & 15,720 & Colon cancer (662) & 6 \\
\hline Michaud et al $^{9}$ (2008) & Cohort & USA & Male & $40-75$ & 48,375 & Colorectal cancer $(1,043)$ & 8 \\
\hline Momen-Heravi et $\mathrm{al}^{8}(2017)$ & Cohort & USA & Female & $39-55$ & 77,443 & Colorectal cancer $(I, \mid 65)$ & 8 \\
\hline Ren et $\mathrm{al}^{7}(2016)$ & Case-control & China & Mix & $40-79$ & 6,619 & Colorectal cancer $(1,063)$ & 6 \\
\hline Ansai et al' (20l3) & Cohort & Japan & Mix & $>80$ & 697 & Colorectal cancer (4|4) & 6 \\
\hline Hujoel et al ${ }^{12}$ (2003) & Cohort & USA & Mix & $25-74$ & II,328 & Colorectal cancer $(3,962)$ & 7 \\
\hline
\end{tabular}


Table 2 Outcomes and covariates of the included studies on tooth loss in relation to risk of colorectal cancer

\begin{tabular}{|c|c|c|c|c|}
\hline $\begin{array}{l}\text { Author } \\
\text { (year) }\end{array}$ & $\begin{array}{l}\text { End } \\
\text { points }\end{array}$ & $\begin{array}{l}\text { Data } \\
\text { source }\end{array}$ & Category and relative risk $(95 \% \mathrm{Cl})$ & Covariates in fully adjusted model \\
\hline $\begin{array}{l}\text { Hiraki et al }{ }^{10} \\
(2008)\end{array}$ & $\begin{array}{l}\text { Colon } \\
\text { cancer }\end{array}$ & $\begin{array}{l}\text { Population- } \\
\text { based }\end{array}$ & $\begin{array}{l}<12 \text { teeth lost, I.0 (reference); }>13-<24 \\
\text { I. } 22(0.97, \text { I.52); }>19-<24, \text { I.II }(0.82 \\
\text { I.50); edentulous, } 0.92(0.56, I .5 \text { I) }\end{array}$ & $\begin{array}{l}\text { Adjusted for age, sex, smoking, and drinking status (never, } \\
\text { former, and current), vegetable and fruit intake, BMl, and } \\
\text { regular exercise }\end{array}$ \\
\hline $\begin{array}{l}\text { Michaud } \\
\text { et al }{ }^{9}(2008)\end{array}$ & $\begin{array}{l}\text { Colorectal } \\
\text { cancer }\end{array}$ & $\begin{array}{l}\text { Self- } \\
\text { administered }\end{array}$ & $\begin{array}{l}<7 \text { teeth lost, I.0 (reference); }>8-<15 \\
0.93(0.78,1.12) ;>16-<32,1.10(0.87 \\
\text { I.37). }\end{array}$ & $\begin{array}{l}\text { Adjusted for age, race, physical activity, history of diabetes, } \\
\text { alcohol, BMI, geographic location, height, calcium intake } \\
\text { (quintiles), total caloric intake (quintiles), red meat intake } \\
\text { (quintiles), fruit and vegetable intake (quintiles), vitamin D } \\
\text { score, smoking history (never; past quit } \leq 10 \text { years, and } \\
\text { past quit }>10 \text { years; current I-14 cigarettes/day [cig/d], } \\
\text { I5-24 cig/d, } \geq 25 \text { cig/d), and pack-years (continuous) }\end{array}$ \\
\hline $\begin{array}{l}\text { Momen- } \\
\text { Heravi et al } \\
(2017)\end{array}$ & $\begin{array}{l}\text { Colorectal } \\
\text { cancer }\end{array}$ & $\begin{array}{l}\text { Population- } \\
\text { based }\end{array}$ & $\begin{array}{l}\text { Colorectal cancer: }<7 \text { teeth lost, I.0 } \\
\text { (reference); 8-15, } 0.94(0.80,1.09) ; \geq 16, \\
\text { I.20 (I.04, I.39). } \\
\text { Colon cancer: }<7 \text { teeth lost, I.0 } \\
\text { (reference); 8-15, } 0.88(0.74,1.04) ; \geq 16, \\
\text { I.I4 (0.97, I.35). } \\
\text { Proximal colon cancer: }<7 \text { teeth lost, I.0 }\end{array}$ & $\begin{array}{l}\text { Adjusted for age, race, smoking before age of } 30 \text { years, } \\
\text { history of colorectal cancer in a parent or sibling, history } \\
\text { of sigmoidoscopy/colonoscopy, current physical activity, } \\
\text { regular aspirin use, multivitamin use, type } 2 \text { diabetes, } \\
\text { alcohol consumption, adult BMI, energy-adjusted intake of } \\
\text { total calcium, vitamin D, folate, red meat and processed } \\
\text { meat, and postmenopausal hormone use }\end{array}$ \\
\hline
\end{tabular}

(reference); 8-15, $0.89(0.72,1.10) ; \geq 16$,

I.23 (I.0I, I.5I).

Distal colon cancer: $<7$ teeth lost, 1.0

(reference); 8-15, $0.86(0.64,1.16) ; \geq 16$, $1.03(0.76,1.38)$.

Rectal cancer: $<7$ teeth lost, 1.0

(reference); 8-15, 1.20 (0.88, I.67); $\geq 16$,

$1.48(1.07,2.05)$.

Ren et $\mathrm{al}^{7} \quad$ Colorectal Population- SWHS/SMHS study

(2016) cancer based Colorectal cancer: 0 teeth lost, 1.0

(reference); I-5, $0.88(0.70,1.11) ; 6-10$,

$0.92(0.69,1.23) ;>10,0.81(0.63,1.06)$.

Colon cancer: 0 teeth lost, 1.0 (reference); $\mathrm{I}-5,0.88(0.64, \mathrm{I} .20) ; 6-10,0.95(0.65$,

I.38); > 10, 0.83 (0.58, I.18).

Rectal cancer: 0 teeth lost, 1.0 (reference);

I-5, 0.89 (0.63, I.27); 6-10, 0.85 (0.54,

I.36); >10, $0.80(0.53,1.21)$.

SCCS study

Colorectal cancer: 0 teeth lost, 1.0

(reference); I-5, I.I 4 (0.72, I.79); 6-10,

0.87 (0.52, I.43); > 10, $1.00(0.63,1.58)$.

Colon cancer: 0 teeth lost, 1.0 (reference);

I-5, I.32 (0.75, 2.30); 6-10, 0.98 (0.54,

I.80); > I0, 0.99 (0.56, I.73).

Rectal cancer: 0 teeth lost, I.0 (reference); I-5, 0.67 (0.27, I.67); 6-10, 0.53 (0.19,

I.45); > 10, 0.98 (0.4I, 2.34).

In SMHS/SWHS, models were adjusted for income, education, BMI, exercise, smoking (never, former, and current), and red meat and fruit consumption

Abbreviations: BMI, body mass index; SCCS, Southern Community Cohort Study; SMHS, Shanghai Men's Health Study; SWHS, Shanghai Women's Health Study.

conducted this comprehensive meta-analysis to clarify the correlation between tooth loss and colorectal cancer risk.

This meta-analysis was based on six studies up to August 2017. Thus, this meta-analysis provides the most up-to-date epidemiological evidence supporting the proposition that tooth loss is harmful in the context of colorectal cancer.
Several plausible pathways may be responsible for the relationship between tooth loss and cancer. The influence of chronic inflammation on cancer development is one possible pathway. ${ }^{16}$ Chronic systemic inflammation is linked to periodontal disease, ${ }^{17,18}$ which is a major cause of tooth loss in adults and can increase the risk of cancer by inhibiting 
Study ID

$\mathrm{RR}(95 \% \mathrm{Cl})$

Hiraki et al ${ }^{10}$ (2008)

Michaud et $\mathrm{al}^{9}$ (2008)

Momen-Heravi et $\mathrm{al}^{8}$ (2017)

Momen-Heravi et $\mathrm{al}^{8}(2017)$

Momen-Heravi et al ${ }^{8}$ (2017)

Momen-Heravi et $\mathrm{al}^{8}$ (2017)

Momen-Heravi et $\mathrm{al}^{8}$ (2017)

Ren et $\mathrm{al}^{7}$ (2016)

Ren et $\mathrm{al}^{7}$ (2016)

Ren et $\mathrm{al}^{7}$ (2016)

Ren et $\mathrm{al}^{7}$ (2016)

Ren et $\mathrm{al}^{7}$ (2016)

Ren et $\mathrm{al}^{7}$ (2016)

Ansai et al ${ }^{11}$ (2013)

Hujoel et al ${ }^{12}$ (2003)

Overall $\left(I^{2}=20.5 \%, P=0.225\right)$

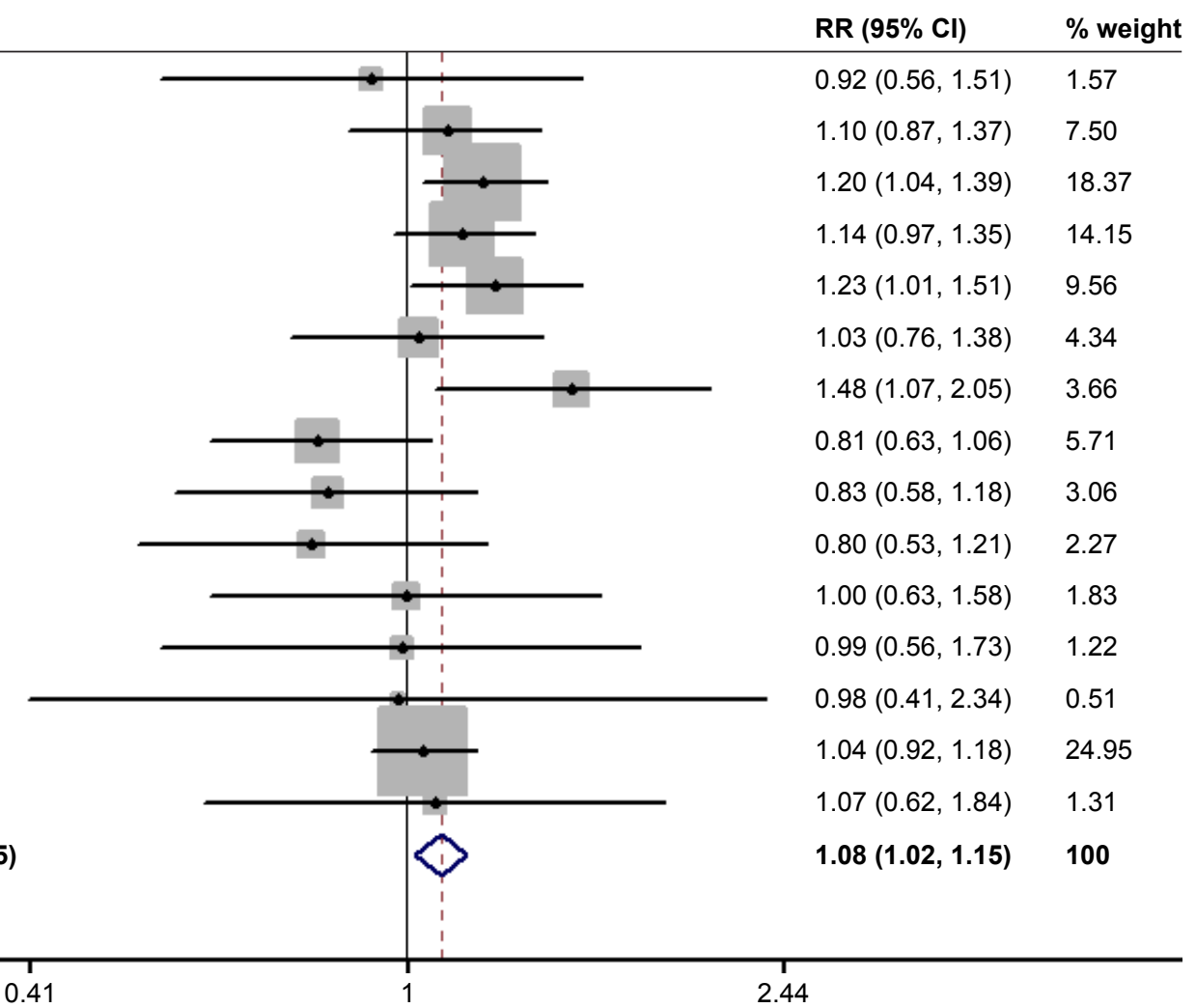

Figure 2 Forest plots of colorectal cancer for the highest versus lowest categories of tooth loss.

Abbreviation: $\mathrm{RR}$, relative risk.

apoptosis and stimulating tumor cell proliferation. ${ }^{19}$ Secondly, the main cause of teeth loss is dental caries, and carbohydrate intake is the cause for dental caries. ${ }^{20}$ Carbohydrate intake is associated with increased risk of cancer; therefore, teeth loss indirectly affects the risk of cancer. ${ }^{21,22}$ Third, the progress of tooth damage destroys normal periodontal tissue, allowing oral microbial accumulation deep into oral tissue,

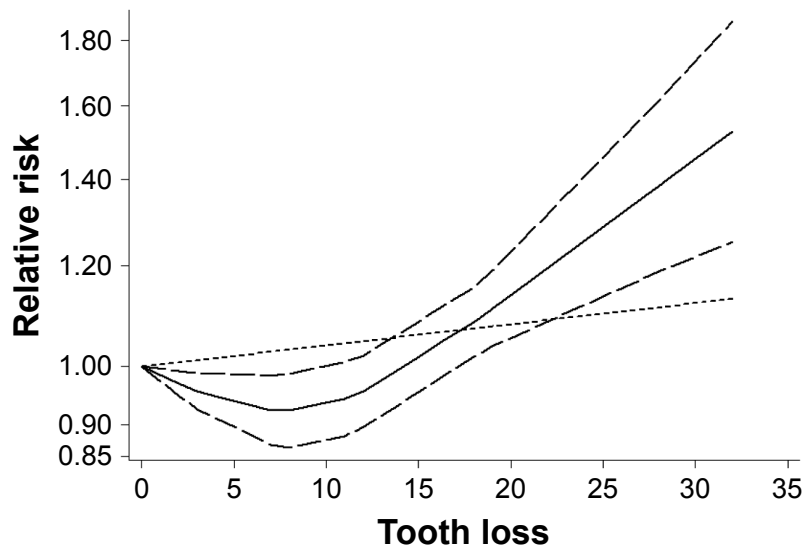

Figure 3 Dose-response relationships between tooth loss and risk of colorectal cancer. thereby promoting its growth. ${ }^{23}$ Thus, tooth loss and cancer seem to be closely related.

To our knowledge, this is the first comprehensive study to identify the association between tooth loss and colorectal cancer risk. Some limitations must be considered in the current meta-analysis. First, we did not consider tumor invasion and metastasis in colorectal cancer, which may have resulted in different results in the subgroups. Secondly, though we found no publication bias in this study, there still existed heterogeneity in the association between tooth loss and rectal cancer. Third, we never tried to search for unpublished research, which may lead to the disappearance of related research.

\section{Conclusion}

Our dose-response meta-analysis suggests that tooth loss is independently associated with deleterious increments in the risk of colorectal cancer. Our findings underscore the notion that increasing tooth loss may be harmful to our health. In the future, large-scale and population-based association studies must be performed to help identify the putative causal role that tooth loss plays in increasing the incidence of these diseases. 
Table 3 Stratified analyses of relative risk of colorectal cancer

\begin{tabular}{|c|c|c|c|c|c|}
\hline Cancer types & $\begin{array}{l}\text { Number } \\
\text { of reports }\end{array}$ & $\begin{array}{l}\text { Relative risk } \\
(95 \% \mathrm{Cl})\end{array}$ & $\begin{array}{l}P \text {-value for } \\
\text { heterogeneity }\end{array}$ & $P^{2}(\%)$ & $\begin{array}{l}P \text {-value } \\
\text { for test }\end{array}$ \\
\hline Colorectal cancer & 15 & $1.08(1.02-1.15)$ & 0.225 & 20.5 & $<0.001$ \\
\hline \multicolumn{6}{|c|}{ Subgroup analyses for colorectal cancer } \\
\hline Colon cancer & 5 & $1.09(1.02-1.17)$ & 0.330 & 14.2 & $<0.001$ \\
\hline Rectal cancer & 3 & 1.08 (I.0I-I.I7) & 0.082 & 60.0 & $<0.001$ \\
\hline \multicolumn{6}{|l|}{ Study location } \\
\hline Caucasia & 7 & I.I8 (I.09-I.28) & 0.695 & 0.0 & $<0.001$ \\
\hline Asia & 8 & $1.06(1.02-1.10)$ & 0.946 & 0.0 & $<0.001$ \\
\hline \multicolumn{6}{|l|}{ Study design } \\
\hline Case-control & 7 & 1.05 (I.0I-I.09) & 0.926 & 0.0 & $<0.001$ \\
\hline Cohort & 8 & $1.17(1.07-1.27)$ & 0.682 & 0.0 & $<0.001$ \\
\hline \multicolumn{6}{|l|}{ Study quality } \\
\hline Score $\geq 7$ & 9 & I.I5 (I.05-I.24) & 0.679 & 0.0 & $<0.001$ \\
\hline Score $<7$ & 6 & $1.08(1.03-1.14)$ & 0.870 & 0.0 & $<0.001$ \\
\hline \multicolumn{6}{|c|}{ Number of participants } \\
\hline$\geq 10,000$ & 8 & $1.16(1.06-1.25)$ & 0.764 & 0.0 & $<0.001$ \\
\hline$<10,000$ & 7 & $1.05(1.01-1.10)$ & 0.557 & 0.0 & $<0.001$ \\
\hline \multicolumn{6}{|l|}{ Number of cases } \\
\hline$\geq 1,000$ & 13 & $1.08(1.02-1.15)$ & 0.125 & 32.2 & $<0.001$ \\
\hline$<\mathrm{I}, 000$ & 2 & $1.04(1.00-1.09)$ & 0.633 & 0.0 & $<0.001$ \\
\hline
\end{tabular}

\section{Acknowledgment}

This study received no specific external funding.

\section{Disclosure}

The authors reports no conflicts of interest in this work.

\section{References}

1. Holleczek B, Rossi S, Domenic A, et al. On-going improvement and persistent differences in the survival for patients with colon and rectum cancer across Europe 1999-2007 - results from the EUROCARE-5 study. Eur J Cancer. 2015;51(15):2158-2168.

2. Miller KD, Siegel RL, Lin CC, et al. Cancer treatment and survivorship statistics, 2016. CA Cancer J Clin. 2016;66(4):271-289.

3. Zeng H, Zheng R, Guo Y, et al. Cancer survival in China, 2003-2005: a population-based study. Int J Cancer. 2015;136(8):1921-1930.

4. Pihlstrom BL, Michalowicz BS, Johnson NW. Periodontal diseases. Lancet. 2005;366(9499):1809-1820.

5. Gerritsen AE, Allen PF, Witter DJ, Bronkhorst EM, Creugers NH. Tooth loss and oral health-related quality of life: a systematic review and meta-analysis. Health Qual Life Outcomes. 2010;8:126.

6. Adegboye AR, Twetman S, Christensen LB, Heitmann BL. Intake of dairy calcium and tooth loss among adult Danish men and women. Nutrition. 2012;28(7-8):779-784.

7. Ren HG, Luu HN, Cai H, et al. Oral health and risk of colorectal cancer: results from three cohort studies and a meta-analysis. Ann Oncol. 2016; 27(7):1329-1336.

8. Momen-Heravi F, Babic A, Tworoger SS, et al. Periodontal disease, tooth loss and colorectal cancer risk: Results from the Nurses' Health Study. Int J Cancer. 2017;140(3):646-652.

9. Michaud DS, Liu Y, Meyer M, Giovannucci E, Joshipura K. Periodontal disease, tooth loss, and cancer risk in male health professionals: a prospective cohort study. Lancet Oncol. 2008;9(6):550-558.

10. Hiraki A, Matsuo K, Suzuki T, Kawase T, Tajima K. Teeth loss and risk of cancer at 14 common sites in Japanese. Cancer Epidemiol Biomarkers Prev. 2008;17(5):1222-1227.
11. Ansai T, Takata Y, Yoshida A, et al. Association between tooth loss and orodigestive cancer mortality in an 80-year-old community-dwelling Japanese population: a 12-year prospective study. BMC Public Health. 2013;13:814.

12. Hujoel PP, Drangsholt M, Spiekerman C, Weiss NS. An exploration of the periodontitis-cancer association. Ann Epidemiol. 2003;13(5): 312-316.

13. Stang A. Critical evaluation of the Newcastle-Ottawa scale for the assessment of the quality of nonrandomized studies in meta-analyses. Eur J Epidemiol. 2010;25(9):603-605.

14. Orsini N, Li R, Wolk A, Khudyakov P, Spiegelman D. Meta-analysis for linear and nonlinear dose-response relations: examples, an evaluation of approximations, and software. Am J Epidemiol. 2012;175(1):66-73.

15. Durrleman S, Simon R. Flexible regression models with cubic splines. Stat Med. 1989;8(5):551-561.

16. Moutsopoulos NM, Madianos PN. Low-grade inflammation in chronic infectious diseases: paradigm of periodontal infections. Ann N Y Acad Sci. 2006;1088:251-264.

17. Kaaks R, Lukanova A. Energy balance and cancer: the role of insulin and insulin-like growth factor-I. Proc Nutr Soc. 2001;60(1):91-106.

18. Loos BG. Systemic markers of inflammation in periodontitis. J Periodontol. 2005;76(11 suppl):2106-2115.

19. Chauncey HH, Glass RL, Alman JE. Dental caries. Principal cause of tooth extraction in a sample of US male adults. Caries Res. 1989;23(3): 200-205.

20. Saunders RH Jr, Meyerowitz C. Dental caries in older adults. Dent Clin North Am. 2005;49(2):293-308.

21. Brand-Miller JC. Postprandial glycemia, glycemic index, and the prevention of type 2 diabetes. Am J Clin Nutr. 2004;80(2):243-244.

22. Sanders TA. How important is the relative balance of fat and carbohydrate as sources of energy in relation to health? Proc Nutr Soc. 2016; 75(2):147-153.

23. Abnet CC, Qiao YL, Dawsey SM, Dong ZW, Taylor PR, Mark SD. Tooth loss is associated with increased risk of total death and death from upper gastrointestinal cancer, heart disease, and stroke in a Chinese population-based cohort. Int J Epidemiol. 2005;34(2):467-474. 


\section{Supplementary materials}

Table SI Results of analysis of publication bias in the metaanalysis

\begin{tabular}{lllll}
\hline Factor & Test & $\boldsymbol{t}$ & $\mathbf{9 5 \%} \mathbf{C l}$ & $\boldsymbol{P}$-value \\
\hline Tooth loss & Begg's test & - & - & 0.621 \\
& Egger's test & -1.24 & $-2.03,0.55$ & 0.239 \\
\hline
\end{tabular}

\section{Funnel plot with pseudo}

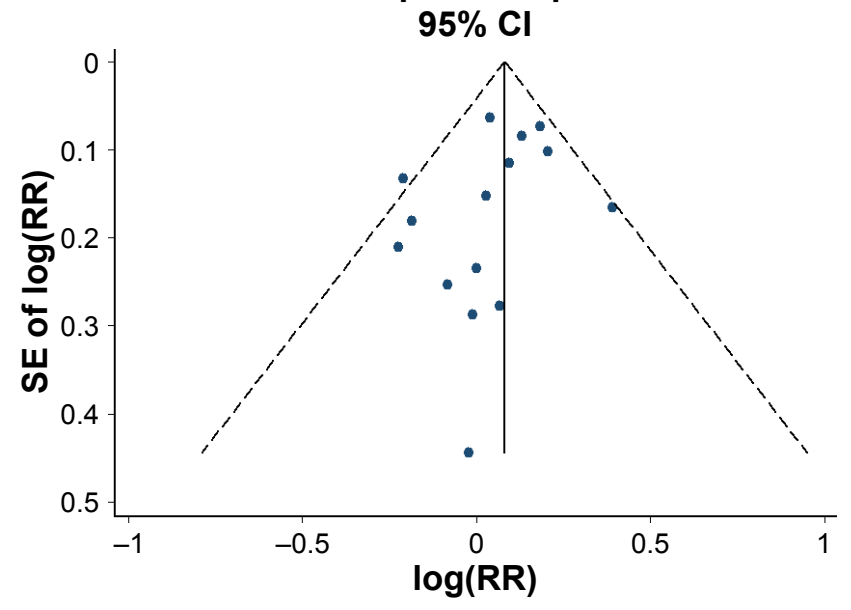

Figure SI Funnel plot of publication bias in studies on tooth loss versus colorectal cancer risk.

Abbreviation: SE, standard error.

\section{Publish your work in this journal}

OncoTargets and Therapy is an international, peer-reviewed, open access journal focusing on the pathological basis of all cancers, potential targets for therapy and treatment protocols employed to improve the management of cancer patients. The journal also focuses on the impact of management programs and new therapeutic agents and protocols on patient perspectives such as quality of life, adherence and satisfaction. The manuscript management system is completely online and includes a very quick and fair peer-review system, which is all easy to use. Visit http://www.dovepress.com/testimonials.php to read real quotes from published authors.

\footnotetext{
Submit your manuscript here: http://www.dovepress.com/oncotargets-and-therapy-journal
} 